\title{
Research in university colleges in Belgium
}

The final publication is available at http://link.springer.com/book/10.1007\%2F978-1-4020-9244-2

Verhoeven, J. C. (2010) 'Research in University Colleges in Belgium' in: Kyvik, S. \& Lepori, B. eds. The Research Mission of Higher Education Institutions outside the University Sector.

Dordrecht/Heidelberg/London/New York: Springer, 97-114. DOI 10.1007/978-1-4020-9244-2_6

Jef C. Verhoeven 


\title{
Chapter 6
}

\section{Research in university colleges in Belgium}

\author{
Jef C. Verhoeven ${ }^{l}$
}

\section{Introduction}

As in many other countries, university colleges (UCs) in Belgium are rather new, having developed mainly after the 1970s. The core business of the UCs was - and for many of the UC teachers still is - to train professionals such as accountants, industrial engineers, infantand primary-school teachers, and nurses. Scientific research was of minor importance, since it has long been considered the domain of universities. Nevertheless, in recent decades, policymakers and some UC managers and teachers have insisted that UCs should also conduct scientific research. This is expressed in the Decree of 13 July 1994 in Flanders and in the Decree of 9 September 1996 in the Francophone Community of Belgium. In spite of this definition of the responsibility of UCs, it would take a considerable amount of time to stimulate UCs to do applied scientific research.

Why did involvement in research come about so slowly? In addition to scientific research being traditionally seen to be the responsibility of the universities, the government provided little research funding for UCs. After the establishment of the federal state structure in Belgium in 1989, the federal government's responsibility for education and research changed totally: research promotion and funding became more the responsibility of the Communities and the Regions. Indeed, Belgium was split into three Communities (Dutch-speaking, Frenchspeaking, and German-speaking) and three Regions (the Flemish Region, the Walloon Region, and the Brussels-Capital Region). Each of these institutions bore some responsibility for education and/or research. Before new areas of emphasis could be established, each of them wanted to establish new educational structures. One of the main objectives of the legislatures, both north and south, was to reduce the number of UCs in their Community in order to improve their organizational management. Before the decrees of the 1990s, there were hundreds of UCs spread out over the country. Flanders, the northern part of the country, established a funding system that was advantageous for large, consolidated UCs (Verhoeven et al. 2002). The policymakers of the southern part, the Francophone Community, were more

\footnotetext{
1 J.C. Verhoeven

Centre for Sociological Research, Catholic University of Leuven, Leuven, Belgium e-mail: Jef.Verhoeven@Soc.Kuleuven.be

S. Kyvik, B. Lepori (eds.), The Research Mission of Higher Education Institutions 97 Outside the University Sector, Higher Education Dynamics 31,

DOI 10.1007/978-1-4020-9244-2_6
} 
lenient but also suggested consolidation. At present, Flanders has 22 UCs, while the Francophone Community finances 46. Although this merging was supposed to be advantageous for the organisation of UCs, the merging process absorbed much energy, so many did not assign research a high priority.

The legislator and UCs were also sensitive to the EU policy. The Lisbon strategy (March 2000) aims to make "Europe, by 2010, the most competitive and the most dynamic knowledge-based economy in the world". Education and research are key instruments for achieving this goal. Following the decision of the European Council the Belgian government and the three Regions took measures to comply (Federaal Planbureau 2006:9), and the UCs are expected to contribute to the process. Since 2003-2004 the Bologna Process as well has greatly influenced because it was a reason for policymakers to reduce the ternary higher education system into a binary system: a professional track in the UCs of 3 years, and an academic track of 4 or more years in UCs and universities.

These European objectives have certainly given an impetus to scientific research in the UCs. Nevertheless, although UCs do more research than they did before, they still are rather modest players in this respect. To explain why they are in this position, we will describe three critical factors: first, the structure of the UCs themselves; second, the Community and Regional research policies in UCs; third, the research strategies in the UCs themselves. We will then review the research performance and conclude with some challenges for the UCs.

\section{The structure of the UCs}

The federal structure of Belgium has put the political responsibility for the organisation of education and a large part of scientific research into the hands of the Communities and the Regions. Although the general structure of higher education in the Flemish and Frenchspeaking Communities is rather similar, there are some differences.

In both Communities alike, UC education is divided into two tracks. Although each Community uses a different terminology, the structure is similar. One stream, the professional, offers education for a professional bachelor's degree, which is a one-cycle programme (3 years). No master programme is offered to these students. The other, the academic stream, offers training for the academic bachelor's degree (3 years) and the master's degree (1 or 2 years), which is a two-cycle programme. It is now possible for a student to move from one stream to another and also to the university, although he or she sometimes is required to pass an admission test to do so. Before the merging process, the UCs generally offered no more than one field of study. At present, they can offer different fields of study. In spite of these similarities between the two Communities, there are also important differences, one being the average size of the institutions: for the 2006-2007 academic year, there were 1,802 students per UC in the south and 4,810 in the north. Another is the structure for the collaboration between the UCs and the universities. 
The Flemish Community has opted for a strong degree of harmonization of the UC academic track with those of the universities. Policymakers expect that the two-cycle academic (bachelor's and master's) programmes of UCs will be "academized" by 2012-2013. What does this mean? UCs should present a detailed planning to guarantee that all academic courses are based on scientific research. They have also to ensure that the teaching staff is engaged in scientific research. They should develop an evaluation system for this process, and report on the use of the special funding for this process. The accreditation organisation NVAO (Nederlands-Vlaamse Accreditatieorganisatie: Netherlands-Flanders Accreditation Organisation) will determine whether this objective has been attained. To achieve this, the UCs can associate themselves with a university. Such an association is an independent body specially founded to realise this academization process. All of the UCs belong to such an association, the meeting place for coordinating the education and research of all of its members. Five associations have been established, the largest of which accounts for about 70,000 students and the smallest for about 8,000. The rectors of the universities (unlike some years ago) speak of integrating the UCs into the universities. The Flemish government has also taken steps in that direction by supporting the establishment in 2007 of the HUB (Hogeschool-Universiteit-Brussel) in Brussels, for which some departments of two UCs and one university in Brussels merged. It offers academic master's degrees. Whether or not the accredited two-cycle programmes will become part of the university system has yet to be determined by law (Boon 2007-2008).

The French Community also favours a rapprochement between the universities and the UCs although its approach has been less coercive than in Flanders. In the French Community, three "academies" were established, each academy being composed of two or more universities. An academy is an independent legal entity with its own financial resources but without any personnel (they are provided by the member universities). Academies organise the $\mathrm{PhD}$ programmes, may grant a $\mathrm{PhD}$ degree, establish graduate schools, organise complimentary master's training, and a centre for didactics. Moreover, they can take initiatives in order to organise education, research, and social services in the academy. In addition to these academies, three "poles" have been established in which UCs can enter into agreements with the university members concerning education and research, but the UC members of a "pole" remain independent.

In 2005-2006, Belgian UCs enrolled 188,883 students and the universities 141,841. This number is still rising though slowly. If the students in the academic stream would be removed from the UCs and counted as university students (which is not as yet the case), the number of enrolments in universities would be 185,383 and in the UCs 145,341 (Vlaams Ministerie van Onderwijs en Vorming 2006, Ministère de la Communauté Française 2006). Some policy makers in Flanders prefer (hope for) this development, but this cannot occur without new legislative steps. In the Francophone Community, policy makers are more hesitant. 


\section{National research policy with regard to UCs}

\section{Strategic goals and guidelines for research}

About 26.6\% of the national research budget in 2006 was in the hands of the federal government (CFS, 2007). The rest of the research budget was the responsibility of the Communities and the Regions. Consequently, most of the UCs' research funding is provided by the Communities and/or the Regions. Although the Communities and the Regions make their own policy, they share some common strategies. For instance, they agreed with the Lisbon strategy to allocate 3\% of the GDP for research in 2010 (High Level Group 3\% Belgium, 2005). Whether this will actually occur is, as yet, uncertain.

Although UCs do not enjoy much of the federal research funding, they follow the federal policy, which is supported by the Communities and the Regions (Federaal Wetenschapsbeleid 2007a), the main providers of funding. In order to meet the target of 3\%, the federal government has opted for the following: the expansion of public expenditure for R\&D, special support for collaboration between private entrepreneurs and public entities, collaboration between federal and regional advisory councils, the increase of research funding in institutions of higher education, the creation of networks of excellence, financial promotion for collaboration between private entrepreneurs and institutions of higher education, a decrease of taxes on salaries for researchers, programmes to attract young researchers, and other measures (CFS 2005).

Very important for the growth of research in Flemish UCs is the academization policy (Vandenbroucke 2006:58), the increased funding by other ministers and the supportive advise for the UCs by the Vlaamse Raad Wetenschapsbeleid (2004; Flemish Council for Science policy).

The Francophone Community of Belgium has a similar policy, although it has no explicit academization policy as in Flanders. In this Community, the responsible Ministers created several programmes to expand the research capacity of the UCs. The idea behind the establishment of the university "poles" (pôles universitaires) is to generate synergy between the UCs and the universities for research. Moreover, many of the sources for funding of research in UCs stress collaboration between UCs and industry (Région Wallonne, Communauté Française 2005).

In both parts of the country, the collaboration between universities and UCs is supposed to contribute to the development of the professional expertise of established and young teachers ${ }^{2}$ in the UCs. Whereas the emphasis in universities is more on fundamental research, UC researchers are more focused on applied research and collaboration with local industry.

\footnotetext{
${ }^{2}$ Teachers in this text refers to UC statutory staff who might teach and conduct research.
} 


\section{Priority setting between teaching and research}

Since the legislation passed in the 1990s, teaching, applied research, and social service provision were stipulated by the government to be the core business of UCs, but in practice attention was mainly paid to teaching. Indeed, the government in both parts of the country did not provide much money to do research. At this time, while research was stressed more than before, the government did not want to make a list of priorities. How UCs use the available time for research or teaching is their responsibility, although the law in the Francophone Community determines how many hours each rank has to teach in a year. However, the academization program in Flanders has certainly put some pressure on the two-cycle programmes to invest more in research than they had been doing. And themes of research that deserve priority are proposed by the Conseil de la politique scientifique de la Communauté Française in Francophone Belgium and the Vlaamse Raad voor Wetenschapsbeleid (VRWB) in Flanders (VRWB, 2004). Both stress the importance of collaboration between the UCs and the universities and industry.

\section{The funding of research}

Within the framework of the Barcelona objectives, the member countries are expected to spend $3 \%$ of their GDP on R\&D in 2010. In 2005, Belgium spent $1.86 \%$ of its GDP on R\&D (Federaal Wetenschapsbeleid 2007a) and has still much to do to attain the 3\% goal. Higher education provided a small part of it. Universities (HERD) spent $0.4 \%$ of the GDP, and UCs $0.01 \%$ (CFS, 2005). The main contribution to R\&D in Belgium comes from private enterprises. Higher education provides only $21.1 \%$ of the R\&D money in Belgium (2007), and only a small part of this is provided by UCs. In the year 2000 , UCs spent only $2.4 \%$ of the research money spent by universities. In 2007, the percentage increased to $4.6 \%$.

The UCs differ not only in having less money to spend for R\&D than universities but also in the importance assigned to the domains of research (Federaal Wetenschapsbeleid 2007). In UCs, no money is available for natural sciences, whereas natural sciences take $22.4 \%$ of the total budget in the universities. In the UCs, $45 \%$ of the expenditure is provided for engineering followed by the social sciences and the humanities. In universities, medical and natural sciences lead followed by engineering and the social sciences.

The positive picture of the HERD of the UCs is that the budget in comparison with 2002 raise with $83 \%$ in 2007 . While the UCs could apply for more money than before, some of the resources could be used only conditionally.

For example, the Francophone Community has especially created for UCs the programme FIRST Hautes Écoles (1991), and "mobilizing programmes" that have to be shared with others. Applications have to be made in co-operation and/or in competition with others. Moreover, UC researchers can apply for funding from the FNRS (National Foundation for Scientific Research), which previously served only the universities (Graitson 2006). 
The Flemish Community offers also special funding for research in UCs. Projectmatig Wetenschappelijk Onderzoek (project-oriented research) and TETRA provide only or mainly funding for UCs, although for the latter a co-operation with the local industry is a condition (Van Looy et al., 2006). Moreover, since 2003, 17 out of the 22 UCs have been receiving a special academization credit for the two-cycle programmes (gradually growing from about $€ 15 \mathrm{MIO}$ in 2006 a year to about $€ 30 \mathrm{MIO}$ in 2009) bringing the research budget from $€ 33$ $\mathrm{MIO}$ in 2005 to $€ 45.5 \mathrm{MIO}$ in 2006 and $€ 57.7 \mathrm{MIO}$ in 2007. Within the new financing system of the UCs, starting in 2008, these special credits will stop in 2012. From then on (if the twocycle programme is accredited), many expect that the UCs will be able to rely on the much larger research grants for universities, but this has to be confirmed by a new law. Others fear that this might impair the critical mass necessary for fundamental research. In addition to these sources, the UCs can also apply for funding in collaboration with universities and/or industry within several other programmes. There is very little participation in European research programmes (Van Ryssen et al. 2007:155, Debackere et al. 2007: 20).

The UCs are free to apply for research funding. No limits are determined by the governments, except that the Flemish UCs that provide two-cycle degrees will have to prove in 2012-2013 that they have a research output that meets the demands of the accreditation organisation NVAO. Until now, neither the law nor the NVAO have published clear standards for determining the academization level. In order to have some guidance, associations refer to the advice of the Werkgroep Academisering (Dekelver, 2007; Gysen et al. 2006, Spruyt et al. 2005-2006).

Table 1. Higher education expenditure on $R \& D(H E R D)$ in UCs and universities in Belgium (2001-2007) differentiated according to the domain of research (in \% and in million $€$ in current prices)

\begin{tabular}{|l|l|l|l|l|l|l|l|l|l|}
\hline & \multicolumn{2}{|c|}{$\mathbf{2 0 0 1}$} & \multicolumn{2}{|c|}{$\mathbf{2 0 0 3}$} & \multicolumn{2}{c|}{2005} & \multicolumn{2}{|c|}{2007} \\
\cline { 2 - 9 } & UCs & Universities & UCs & Universities & UCs & Universities & UCs & Universities \\
\hline $\begin{array}{l}\text { Natural } \\
\text { sciences }\end{array}$ & 0.0 & 24.7 & 0.0 & 22.8 & 0.0 & 22.1 & 0.0 & 21.4 \\
\hline Engineering & 54.1 & 16.0 & 47.6 & 16.0 & 48.1 & 16.0 & 45.3 & 17.5 \\
\hline $\begin{array}{l}\text { Medical } \\
\text { sciences }\end{array}$ & 3.8 & 24.5 & 7.2 & 24.5 & 7.6 & 26.8 & 6.8 & 27.7 \\
\hline $\begin{array}{l}\text { Agricultural } \\
\text { sciences }\end{array}$ & 17.5 & 10.9 & 11.9 & 11.2 & 7.9 & 10.7 & 6.5 & 9.6 \\
\hline $\begin{array}{l}\text { Social } \\
\text { sciences }\end{array}$ & 15.4 & 16.2 & 20.0 & 17.6 & 20.4 & 16.8 & 26.1 & 15.8 \\
\hline Humanities & 9.1 & 7.7 & 13.2 & 7.9 & 15.9 & 7.6 & 15.2 & 8.0 \\
\hline Sum & 100.0 & 100.0 & 100.0 & 100.0 & 100.0 & 100.0 & 100.0 & 100.0 \\
\hline $\begin{array}{l}\text { Total } \\
\text { HERD }\end{array}$ & 25.3 & $1,013.6$ & 33.7 & $1,087.6$ & 36.2 & $1,174.2$ & 57.7 & $1,251.6$ \\
\hline
\end{tabular}

Source: Commissie Federale Samenwerking, Overleggroep CFS/STAT 


\section{The research strategies in UCs}

Although research was not the primary concern of the UCs in the 1990s, the wish of some UC staff and also the Bologna Process has opened the prospects for more research in UCs. This was not an obvious objective, which is confirmed by the low figures of Table 1. Even though the legal structure had already been accepted by the parliaments in 2003 and 2004, the amount of research money spent by UCs is still low. In the meantime, this has changed for the better, more in the Flemish (because of the academization policy) than in the Francophone Community. To check whether this new policy can introduce a change in the research behaviour of UCs, we conducted case studies (November 2007-January 2008) of one association in Flanders and one pole in the Francophone Community in which the universities are strongly research orientated. In each, we studied two UCs. For an overview of the research strategy during the 1990s we rely on previous research.

The Flemish association with 12 UCs in this study is the largest in Flanders (about 70,000 students) and is involved with a research-oriented university. Two of these UCs were studied in some detail. One offers only professional bachelor degrees (later A1), and the second (later A2) offers two-cycle programmes in addition to professional bachelor's programmes. Each of these UCs has slightly fewer than 5,000 students enrolled. Unlike most of the other UCs, A2 has more than 25 years of research experience and accounts for a fifth of the about $€ 26 \mathrm{MIO}$ research money allocated to all of the UCs of the association in 2006. A1 had a research budget of $€ 600.000$ in 2007.

The Francophone pole (about 35,000 students) is linked to an "académie" composed of three universities, but the pole itself consists of one university, a university institution, five UCs, two schools for architecture, and four art schools. Two of the UCs, each with about 2000 students, were examined. Both of the UCs offer professional bachelor's programmes and academic master's programmes. Although this pole mentions as one of its targets to "guarantee and reinforce the complementarity of the research of the university and the UCs", it has hitherto focused more on educational co-operation. Therefore, the research collaboration between the university and the two observed UCs is on a personal basis. Between 2004-2007, P1 had a research budget of at least $€ 800,000$. One research unit of P2 has a research tradition that goes back to the $19^{\text {th }}$ century. According to the director, his unit has at its disposal $50 \%$ (or about $€ 2$ million in 2006) of the research money provided by the Walloon Region to UCs for research. This unit had occupied its strong position already before the Bologna process had begun.

This focus on more research-oriented UCs in these case studies reveals that many UCs cannot attain that level of research. Nevertheless, focusing on research-oriented colleges might unveil what UCs can do in the field of research if they act like the more experienced colleges. 
In this section, I will discuss five issues: the institutional strategy of the UCs, the organisation and management of research, the collaboration with universities and industry, human resources and careers, and the allocation of the research resources.

\section{Institutional strategy and priority setting}

In many of the UCs, research was a choice made by individual researchers. While some of the more established research units had formulated an institutional strategy, most had not. This has changed now in Flanders because of the academization process. Association A has set up a research council in which the university and UCs are integrated. This research council has formulated a 48-page strategic plan for 2007-2011, and each UC offers within the same framework a strategic plan of 8 to 20 pages. Agreements are made between faculties and departments of the university and the UCs. Some faculties integrated the faculty of the university and the UCs (e.g. linguistics) into one faculty, others, when the type of research was different, established an associated faculty (e.g., engineering). In 2008 this association announced the integration of the UC master programmes in the university in 2013. The interviewees in A2 stressed that even when the department had become part of an associated faculty, the strategic plan of the UC was formulated by themselves. Although Association A has adopted a strategic plan for the research provided in the professional track, there is less coherence in this research. Because of the modest budget for research in this track and the many fields of research, only a few applicants can be financed. In A1, three research projects can be granted each year, and in $\mathrm{A} 2$ the number is between 3 and 6 .

The pole did not develop a strategic research plan and is still focused on collaboration for the organisation of education between universities and the UCs. In P2, some of the institutes and departments developed a strategic plan, and one of its established institutes had long one. Whether these strategic plans will have the desired effect, the future will show.

\section{The organisation and management of research}

The organisation of research differs between the north and the south of the country. In Flanders, at present, associations are very important for research, but this is not the case for the poles in Francophone Belgium. Although there is cooperation between the universities and the UCs in the French Community, the UCs determine independently what research they do and how they go about it. The UCs do have a research council, but it is up to each teacher to apply for research funding and to manage his or her own research. Some research units of the academic track in P1 and P2 have an established management structure, but most research projects of the professional track are organised by an individual research director.

Since the establishment of the Association, the management of research in UCs has changed. Until then, whether or not to do research was the free choice of a teacher, but since the commencement of the compulsory academization process, the academic track in the UCs cannot do without research. Moreover, the universities became important parties in this 
process. In Association A, this is apparent in its organisation, the advisory research councils for the association, the formulation of strategic plans, the integration or association of departments of UCs with faculties of the university, etc. But, after deliberation among the different parties, it is still the responsibility of each research director to search for money and to manage the project. Both A1 and A2 have a research council and one or two coordinators of research, but this does not diminish the responsibility of each research director. Within the framework of the academic track, A2 has a research institute in which seven sections are functioning. In an interview, a head of a department hopes that, in the future, the UCs will be able to organise their own $\mathrm{PhD}$ programmes because the type of research of the UCs differs from that of the universities. Up to the present, however, granting $\mathrm{PhD}$ degrees is the privilege of the university.

\section{Collaboration with universities and industry}

Research has shown that the academic drift was still not very pronounced in UCs at the end of the 1990s. On the contrary, teachers, students, and employers saw a different type of students in UCs than in universities. The UC courses were supposed to teach students readily usable skills for particular occupations, whereas university courses are less application oriented and lead to many kinds of occupations (De Wit \& Verhoeven 2003). In 2001, in a survey of UC teachers, we asked the question: "To what extent does your UC collaborate with universities for doing research?" Few teachers recognized collaboration with universities (Verhoeven et al. 2002). No longer ago than 2000, Zwerts and Hollebosch (2000:42) stated that UCs wanted to be more independent from universities as far as research is concerned.

This has changed now. The Bologna Process brought the UCs and the universities, willy-nilly, closer to each other in Flanders because it led to the establishment of associations and in the Francophone Community to the creation of opportunities to collaborate within the academies and/or poles. The UCs of the pole of our case studies, however, had not changed very much as far as their contact with universities is concerned.

The situation differed in Flanders. Associations were created by law and are the only route to academization of the UCs. Therefore, Association A created a structure in order to bring not only the teaching but also the research of the university and the UCs closer to each other. This did not destroy the independence of the UCs, but opened for them new forms of collaboration. For instance, researchers of the UCs can become affiliated with the university; UC applicants may apply for research funding together with university colleagues; fields of research can be adapted to each specialty; and, in the near future, UC teachers may be appointed to an associate position at the university.

The industry in general, trading companies, and social-profit organisations have long been the natural allies of the UCs. To offer their students practical training they needed these organisations. These contacts not only provided trainee posts but also opened opportunities 
for collaborating in research. The government supported this situation by creating special research programmes in which industry collaborates with UCs or universities. Association A was very entrepreneurial in this programme. Of the 234 TETRA projects from 1997 to 2006, Association A accounted for some 52\% (Van Ryssen et al. 2007:68). In 2004-2007, P1 was awarded 4 FIRST programmes, and P2 eight FIRST and five other projects, among which were three from the FNRS, a resource traditionally the privilege of the universities. In addition to such projects, UCs often do smaller projects for the industry.

Although the interviewees appreciate collaboration with industry, they mentioned some problems. First, research conducted for industry limits the opportunity for publication, as industry often considers the results as private property. Second, a research programme that makes the approval dependent on the collaboration with industry might hinder the application process as private companies are not always very eager to fill out the forms. An interviewee hoped that the academization process would give more opportunities for research grants without being obliged to involve a private company.

\section{Human resources and careers}

When the legislatures enacted new laws in the 1990s, they changed the names and ranks of the teaching staff of UCs. The Francophone Community and the Flemish Community acted differently. In Flanders, three groups are distinguished (see Table 2). Group 3 is identical to the ranking system of the universities, and these positions may be granted in both the professional and the academic track. Most of these teachers teach in the academic track and should in principle have a $\mathrm{PhD}$ degree (bold in Table 2), but under some conditions these positions are also open to civil engineers. In the future, because of the academization policy, most of them are supposed to have a PhD. These principles apply also to Rank 2 of the Francophone Community. Nevertheless, only the title of professor is the same as in universities; the two other titles do not have the same meaning as in the universities. The "chef de travaux" may be called a junior lecturer, and the "chef de bureau d'études" has the same position and salary as the assistant professor in universities (or in Flemish UCs) but spends most of his time managing the organisation of teaching.

Table 2. Types of academic staff in UCs in Flanders and the Francophone Community

\begin{tabular}{|l|l|l|l|l|}
\hline Flanders Group 1 & $\begin{array}{l}\text { Francophone } \\
\text { Community Rank 1 }\end{array}$ & $\begin{array}{l}\text { Flanders } \\
\text { Group 2 } \\
\text { (auxiliary } \\
\text { staff) }\end{array}$ & Flanders Group 3 & $\begin{array}{l}\text { Francophone } \\
\text { Community Rank 2 }\end{array}$ \\
\hline $\begin{array}{l}\text {-junior practical lector } \\
\text { (praktijklector) }\end{array}$ & $\begin{array}{l}\text {-Maître de formation } \\
\text { pratique }\end{array}$ & $\begin{array}{l}\text { - research } \\
\text { assistant } \\
\text {-senior practical lector } \\
\text { (hoofdpraktijklector }\end{array}$ & $\begin{array}{l}\text { - Maître principal de } \\
\text { formation pratique } \\
\text { (rang 2) }\end{array}$ & $\begin{array}{l}\text {-doctoral } \\
\text { assistant }\end{array}$
\end{tabular}




\begin{tabular}{|c|c|c|c|c|}
\hline $\begin{array}{l}\text {-junior lector (lector) } \\
\text { - senior lector } \\
\text { (hoofdlector) }\end{array}$ & $\begin{array}{l}\text {-Maître assistant } \\
\text {-Chargé de cours }\end{array}$ & $\begin{array}{l}\text { (doctor- } \\
\text { assistent) } \\
\text {-senior } \\
\text { researcher } \\
\text { (werkleider) }\end{array}$ & $\begin{array}{l}\text { (hoogleraar) } \\
\text { - professor (gewoon } \\
\text { hoogleraar) }\end{array}$ & $\begin{array}{l}\text { - Chef de bureau } \\
\text { d'études }\end{array}$ \\
\hline
\end{tabular}

Group 1 in Flanders and Rank 1 in the Francophone Community is composed of different ranks of teachers teaching the professional bachelors' courses. They teach professional practice and theory. Two positions in the Francophone Community are different from the Flemish situation. The "Maître principal de formation pratique" actually belongs to Rank 2, and the "chargé de cours" is supposed to have a $\mathrm{PhD}$, but, as already noted, this is not necessary. For the first two positions in Group 1 and Rank 1, the candidate needs to have a $\mathrm{BA}$; the other positions require at least an MA.

Salaries vary according to the position of the teacher and seniority. There is no extra salary for teachers doing research, but they may receive part of the profits based on the inventions in which they are involved.

Most UCs were accustomed to selecting teachers solely on the basis of their teaching abilities. In the meantime, this has changed. Teaching abilities are still very important, but teachers for the two-cycle programme are, more than previously, being selected for their interest in research and the ownership of a $\mathrm{PhD}$. This is not the case for the teaching staff of the onecycle BA programmes.

Since research became more important, it could be expected that teachers who are also involved in research would have more opportunities for promotion. This is the case in A2 and $\mathrm{P} 2$, but much less in the other cases. Moreover, there is some hesitation also in A2. If a teacher without a $\mathrm{PhD}$ does a good job, he or she can also be promoted, a principle that is supported by the unions. Although the hierarchy shown in Table 2 varies considerably, there are few opportunities for promotion because of the modest budgets of the UCs and the age structure of the staff (Verhoeven 2005; also in P1).

The equivalents of university positions, the first four rows of Table 3,14.6\% of the staff in Flanders and $12.8 \%$ in the Francophone Community, is the smallest group among the teachers. With these figures, one might expect that this is the proportion of teachers having a $\mathrm{PhD}$. Nevertheless, information from the Association shows that not all bearers of these titles have a PhD. In Association A in most domains of study less than 55\% of the teachers have a $\mathrm{PhD}$ (Gysen et al. 2006). The total number of teachers with a PhD in Flemish UCs is certainly less than $14.6 \%$. How much less is hard to tell because teachers in the other ranks may also have a PhD. ETNIC calculated that in the Francophone Community $6.8 \%$ of their UC teachers have a PhD. 
Table 3. Teaching staff (only main categories) in UCs in Flanders (FTE) and Frenchspeaking Community (persons; sample of UCs) by rank and tenureship in February 2007 (N and \%).

\begin{tabular}{|l|l|l|l|l|l|l|}
\hline & \multicolumn{2}{|l|}{ Flanders } & \multicolumn{3}{l|}{ French-speaking Community } \\
\hline & Provisional & $\begin{array}{l}\text { Permanent } \\
\text { appointment }\end{array}$ & Total & Provisional & $\begin{array}{l}\text { Permanent } \\
\text { appointment }\end{array}$ & $\begin{array}{l}\text { Total } \\
\text { Rank }\end{array}$ \\
\hline Professor & 0.1 & 0.5 & 0.4 & - & - & - \\
\hline Assistant Professor & 0.1 & 3.8 & 2.3 & - & 4.5 & 2.7 \\
\hline Senior Lecturer & 0.4 & 2.5 & 1.6 & - & - & - \\
\hline Junior Lecturer & 8.8 & 11.4 & 10.3 & 0.2 & 17.0 & 10.1 \\
\hline $\begin{array}{l}\text { Senior lector, senior researcher, } \\
\text { doctoral assistant }\end{array}$ & 2.1 & 6.1 & 4.4 & 19.5 & 10.7 & 14.4 \\
\hline Junior Lector, research assistant & 70.0 & 59.5 & 63.8 & 33.8 & 25.7 & 29.0 \\
\hline Senior Practical Lector & 0.1 & 0.6 & 0.4 & - & 1.4 & 0.8 \\
\hline Junior Practical Lector & 18.4 & 15.6 & 16.8 & 46.5 & 40.7 & 43.0 \\
\hline Sum & 100.0 & 100.0 & 100.0 & 100.0 & 100.0 & 100.0 \\
\hline Total N & 2908.98 & 4159.93 & 7068.91 & 1228 & 1768 & 2996 \\
\hline
\end{tabular}

Source: Department of Education (Ministry of the Flemish Community) and ETNIC. Our own calculations.

The small amount of funding for research (see Table 1) and the small number of staff of group 3 or rank 2 (see Table 3) is a foreshadowing of the small figures of the UCs in Table 4. UCs had only $2.7 \%$ (in FTE) of the number of researchers in universities in 2000, and $5.2 \%$ in 2007. In 2007, only $40.2 \%$ of them were female (CFS).

Table 4: R\&D personnel in UCs and universities in Belgium (2000-2005) classified as researchers, technical personnel, and other personnel (FTE)

\begin{tabular}{|l|l|l|l|l|l|l|}
\hline Year & \multicolumn{5}{|l|}{ UC } & \multicolumn{4}{l|}{ Universities } \\
\hline & Total & Function & \% of year total & Total & Function & \% of year total \\
\hline 2001 & 488.8 & Researcher & 73.3 & $15,502.8$ & Researcher & 74.3 \\
\hline & & Technician & 10.2 & & Technician & 17.5 \\
\hline & & Other & 16.5 & & Other & 8.1 \\
\hline 2003 & 624.0 & Researcher & 82.5 & $15,630.1$ & Researcher & 74.8 \\
\hline & & Technician & 8.1 & & Technician & 16.6 \\
\hline & & Other & 9.4 & & Other & 8.6 \\
\hline 2005 & 702.3 & Researcher & 93.2 & $16,759.6$ & Researcher & 77.3 \\
\hline & & Technician & 4.1 & & Technician & 15.1 \\
\hline & & Other & 2.7 & & Other & 7.6 \\
\hline 2007 & 996.3 & Researcher & 94.2 & $18,206.2$ & Researcher & 78.5 \\
\hline & & Technician & 2.6 & & Technician & 13.0 \\
\hline & & Other & 3.2 & & Other & 8.5 \\
\hline
\end{tabular}

Source: Commissie Federale Samenwerking, Overleggroep CFS/STAT

Other research confirms that teachers of UCs did not invest very much effort in research in the 1990s. A survey conducted in 2000 in Flanders showed that about $9 \%$ of the teachers of the UCs $(\mathrm{N}=4,043)$ reported that they did research. $68 \%$ of this small group spent only 1 day a week on research in the first semester, and in the second semester between 2 and 5 hours a 
week (Smolders et al. 2000:75). Research was very often seen by the teachers as a burden that had to be done in addition to teaching (Zwerts \& Hollebosch 2000). Moreover, most of the research projects were rather brief in duration and did not deliver much satisfaction to the researchers. The consequence was that a research culture was not supported by a large part of the teachers in the UCs.

Nevertheless, in spite of the still low figures given in Table 1, we suggest that this picture is changing. Above we have seen that the Bologna Process pushed the policy makers to change the law and brought the two-cycle programmes in the UCs closer to those of the universities. The Associations are seen as the basic organisation for coordinating this academisation process and more money is being made available for research. A1 (33 contractuals in 2007) and A2 (65 contractuals) can more than before hire contractual researchers to do research in collaboration with the tenured teachers.

Although the policy in Francophone Belgium is different, the UCs there are also now being given more opportunities to do research than previously. But here, more than in Flanders, research is concentrated in a small group of established UCs. For instance, between 2004 and 2007, P1 had as many as seven additional contractual researchers. P2 hired 17 contractuals and one research institute of $\mathrm{P} 2$ has had a staff of about 20 appointed researchers for many years.

In 2000, of a sample of 4043 UC teachers in Flanders, only 48 were working for a PhD (Smolders et al. 2000:76). This has changed now. In Association A: 14.7\% of the staff in Economics, $11 \%$ in Applied Linguistics, and in Engineering 37 candidates are working for a $\mathrm{PhD}$ (Gysen et al, 2006). This positive development is also supported by new programmes. TETRA, for instance, launched $30 \mathrm{PhD}$ candidates (Van Ryssen et al. 2007: 191), who have yet to obtain their degrees. Whether this will come up to the criteria of academisation, has to be proven.

\section{The allocation of resources for research}

For the allocation of the resources for research, the general principle is that the applicant who received the contract is responsible for its implementation. This means that the money is at her/his disposal. Depending on the UC policy, the applicant can replace some of her/his teaching by working on a project or/and can hire contractuals to do the research. The special academization grant, which most of the UCs of Association A receive, is used for the research projects of the $\mathrm{PhD}$ students and of teachers with a $\mathrm{PhD}$ doing research as part of the academization process.

Although there is now a more positive attitude towards research, this was not the case in the 1990s. Research was considered as something to do in addition to teaching (Zwerts \& Hollebosch, 2000), even though the Flemish law allowed the UCs themselves to decide about 
the division of labour. This was not so in the Francophone Community. Here the law prescribes the number of teaching hours per year.

In Flanders in 2001, the average weekly working load was 44 hours. At average a teacher had to teach 14 hours a week. This means that the average teacher used about 30 hours weekly to prepare classes and/or to do research. However, about $60 \%$ of the teachers did no research at all. In relation to research, it is interesting to know that teachers having a $\mathrm{PhD}$ did not teach less than did teachers without a PhD (Verhoeven 2005).

This has changed now in Association A. This Association has put the target that an "active researcher" should spend at least $20 \%$ of a full-time position on research. A2 even decided to strive for $30 \%$. In A1 and A2, a wide variety of measures are being taken to open more possibilities to do research. Nevertheless, this is not without problems. In A1, for instance, it is possible for a teacher to change teaching hours into research hours. The problem later on is that this teacher might have difficulties in returning in his former teaching position. Another problem is the pressure of the unions to reduce the number of contractuals because this position is less appreciated than a statutory position. The policy of $\mathrm{P} 1$ and $\mathrm{P} 2$ is partly different, partly similar. In P1, large projects are conducted mainly by professors. Other staff members have to teach 16 or more hours a week, and only a few of them do research. In P2, professors have to teach less than the law has determined. Instead of 360 hours a year, they teach 200 hours.

\section{Research performance}

\section{The extent and output of research}

It is not surprising that UCs publish less than universities, apply for fewer patents, and establish fewer spin-offs. This is to be expected because the research budgets of UCs are so much smaller than those of the universities, and publishing is not part of the culture of the UCs. This attitude is sometimes supported by the demands of the private company with which they collaborate as such companies do not want the results to be published. Nevertheless, their output is visible in SCIE and SSCI. Bart Thijs (Steunpunt O\&O Indicatoren, KU Leuven) calculated that, in 1992, the UCs published 1.3\% of the 5,757 Belgian publications reported in these indexes, whereas the universities published $99.4 \%$. In 2005 , these figures were respectively $1.6 \%$ of the 11,897 publications and $98.9 \%$. Between 1992 and 2005, the UCs published $1.2 \%$ and the universities $99.1 \%$ of the publications $(\mathrm{N}=$ $118,416)$. Only $0.9 \%$ was published by UC researchers alone. Moreover, research by Bart Van Looy (Steunpunt O\&O Indicatoren, KU Leuven) found that a UC of Association A had applied for 2 patents of a total of 825 patents in Belgium between 1989 and 2004 . He also stated that, in this period, 4 spin-offs were established by UCs, one of them by P2 (see also Debackere \& Veugelers 2007). 
Nevertheless, although the small group of publishing teachers did not often publish in first rate journals, there is a wider publishing activity. Within the framework of TETRA (19972006), about 600 articles were published, about 200 websites, manuals, etc. $65 \%$ of the projects contributed to new calculation models or simulations. Ten patents were applied for by the collaborating private company (Van Ryssen et al. 2007:189-198).

Because the academization target has to be attained in 2012-2013, Association A monitors some indicators, one being publications. Although the publication activity is still small, there is some increase (Gysen et al. 2006:31). For the publications of books and papers in local journals the UCs approach the results of their university counterparts.

\section{The relevance of research for the regional community and for the development of professional expertise}

Until the 1990s, hundreds of small UCs were spread over the country. The distance between the old UC and local business, government, schools and welfare organisations was small. This made contacts between UCs and the region easy, and after the merger these links did not disappear. Research was often conducted in collaboration with local industry. This more application-oriented research is the type of research often practised by teachers of the professional track, and industrial research was mostly a service to local SMEs (Van Ryssen et al. 2007:70,190). The regional community seems to appreciate this collaboration, a statement that is confirmed by our four case studies.

All the interviewees also saw this type of research as contributing to the professional expertise of teachers and students. Indeed, this type of research created opportunities to encounter the everyday practice of a profession. For the Associations in Flanders, research is even more important because it is the basic criterion for obtaining entrance into the system of academic education. Therefore, Association A has created a system to determine whether the Association is making progress in the academization process. This does not mean that the contact with the regional environment should be reduced. The TETRA projects, for instance, opened the road for about 400 to 450 researchers to move from UCs to companies (Van Ryssen et al. 2007:190). The same phenomenon was mentioned in our four case studies.

\section{Conclusions and challenges}

Until the 1990s, Belgian UCs were not accustomed to investing much in research. Research in UCs was the initiative of some individuals, and some were able to establish research units. Nevertheless, the research resources available for the UCs were only a small fraction of what universities got for research.

Since 2003-2004 the climate changed. During the 1990s small UCs were consolidated to bigger units, and under the influence of the Bologna process policymakers wanted to reinforce the link between UCs and universities by creating associations and poles. These new 
organisations seem to be stronger in Flanders than in the French-speaking Community, although some "academies" announced to make the collaboration stronger starting in 2010. This policy was accompanied by more funding for research, the obligation to participate in the academisation policy (only in Flanders), and more supervision (possible accreditation in 2012-2013 in Flanders). Nevertheless, because of the recent character of this policy, it is still too early to assess to what extent this policy will change the production of research in the UCs, or to what extent universities will benefit more from this policy than UCs, as some suggest.

Various scenarios are possible. UCs may integrate in universities or not and the academic masters programmes of the UCs may be accredited or not (only in Flanders). Each scenario will bring new challenges for the development of research in UCs.

Merging of UCs and universities might put an end at the binary system, but this will not happen for free ${ }^{3}$. At the national level the laws should be adapted and funding should be brought at the level of the universities. At the university level management and staff might face a lot of problems. For instance, how to consolidate the missions of UCs (composed of one-cycle professional and two-cycle academic programmes) and universities? How to integrate the different research and teaching culture? How to distribute the meagre research funding? How to keep the standards, etc.?

The second scenario, when there is no merging, does not leave the UCs untouched either. Unless the current policy is changing, they still will have to cope with very small research funding, and teachers who have to integrate a research culture with the predominant teaching culture. Moreover, research standards are made up by the international scientific community and have to be met.

The third scenario, the accreditation of the UCs, will not solve all problems either. One of them is the legal position of the association. Will the association structure be continued or will policy makers opt for the merger of UCs and universities? Will UCs (or only the two-cycle courses) become part of the university or will they keep their independence? Will the government expand the funding for research to satisfy the increased demands? Should accredited UCs be obliged to leave the applied research track?

What about institutions that did not earn the accreditation (the fourth scenario)? What will be their position after loosing a provisional accreditation? What will be the consequences for the graduates of these UCs? Will the additional research funding offered during the academisation process still be available and can they try again to get accredited?

\footnotetext{
${ }^{3}$ When this book was sent to the printer a special commission had advised the Minister of Education to merge the training for academic degrees of the UCs and the universities. UCs were advised to offer only the professional degrees (Ministeriële Commissie, 2009).
} 
Whatever direction UCs are developing, our observations confirm that research is concentrated in some UCs, and that in each UC not all staff members share the research culture of their colleagues of strong research units. For many staff members, attention to research in the UCs came too late in their career, and investing in research did not always seem to be a guarantee for promotion. This might slow down the interest in research.

In Flanders, the attention has focussed on the academization process. Several experts doubt whether this is possible in the provided span, and with a much smaller budget than the universities. Although a ministerial assessment committee is moderately positive about the provisional results on the road to academisation, it warns in its report of 16 November 2008 that "...there still is the real danger that the academisation process might ultimately experience a little satisfactory result" (Erkenningscommissie, 2008). Some also feared that UCs would conduct research that was the privilege of the universities. This opinion is not shared by most of our interviewees. Both, universities and UCs, hope that the UCs will maintain the individuality of their research and do not move to types of research popular at the universities. They also wish one can obtain the right to apply for research funding from foundations that has been and still is the privilege of universities. This is different in onecycle programmes. Here the available research funding is much less than for the two-cycle programmes. The interviewees expect that research will be able to maintain its own character but they also hope that more funding will be available and that research will become part of the job description of the teachers and subject of quality assurance.

But in spite of this new policy, scientific research in UCs is still modest and receives only a fraction of the research funding of the universities. Nevertheless, this new policy has given UCs a boost to do research. Whether this process will continue and even expand, only the future can tell.

\section{Acknowledgements}

* I want to thank Kurt De Wit, Svein Kyvik, and Benedetto Lepori for their critical comment on this chapter.

\section{References}

Boon, A. (2007-2008) Associatie: quo vadis - waar ga je heen? Tijdschrift voor Onderwijsrecht en Onderwijsbeleid (1-2), 3-17

CFS (2005). Bijdrage van de departementen Wetenschapsbeleid aan het Nationaal Actieplan ter uitvoering van de Lissabon-agenda. Brussel, Retrieved on November 1, 2007, from www.belgium.be/eportal/ShowDoc/chancellery/imported_content/pdf/Bijlage1_Onderzoek_e n_ontwikkeling.pdf?co...: 
CFS (Commissie Federale Samenwerking van de Interministeriële Conferentie voor Wetenschapsbeleid/Commission Coopération Fédérale de la Conférence Interministérielle de la Politique Scientifique) (2007). Budgettaire kredieten voor $O \& O$ van de overheden in België in de 1995-2006/Crédits budgetaires de R\&D des autorités Belges au cours de la période 1995-2006. Brussel: Federaal Wetenschapsbeleid - Politique Scientifique Fédérale

Commissie Federale Samenwerking van de Interministeriële Conferentie voor Wetenschapsbeleid (CFS) - Commission Coopération Fédérale de la Conférence interministérielle de la Politique scientifique (2009) Onderzoek en ontwikkeling door de nonprofitorganisaties in België in 2006 en 2007. Recherche et développement dans les organisations du secteur non marchand en Belgique en 2006 et 2007. Brussel : Federaal

Wetenschapsbeleid - Politique Scientifique Fédérale. Retrieved on September 3, 2009 from http://www.belspo.be/belspo/home/publ/pub_ostc/ind/OO_200607_2.pdf

De Wit, K. \& Verhoeven, J.C. (2003). The context changes but the divisions remain. The binary education system in Flanders (Belgium). The case of information science. Studies in Higher Education, 28, 143-156

Debackere, K. \& Veugelers, R. (Eds.). (2007). Vlaams Indicatorenboek 2007. Brussel: Vlaamse Overheid/Steunpunt O\&O Statistieken.

Dekelver, N. (2007). Academisering. Welke koers? Delta. Tijdschrift voor Hoger Onderwijs. (December), 26-32.

Erkenningscommissie (2008) Rapport van de Erkenningscommissie Hoger Onderwijs inzake de Voortgangstoets van de Academisch Gerichte Opleidingen van de Hogescholen in Vlaanderen. Brussel, $55 \mathrm{pp}$

Federaal Planbureau (2006). Lisbon strategy. National reform programme 2005-2008 Belgium. More growth, more jobs...Progress report 2006. Brussel: Federaal Planbureau.

Federaal Wetenschapsbeleid (2009). O\&O-Statistieken. Brussel: Federaal Wetenschapsbeleid. Retrieved on September 3, 2009, from http://www.belspo.be/belspo/stat/index_nl.stm

Federaal Wetenschapsbeleid (2007a). O\&O-Activiteiten in België in 2005. Overzicht van de resultaten van de O\&O-enquętes 2006. Brussel. Retrieved on November, 3, 2007 from http://www.belspo.be/belspo/home/pers/20070718_nl.pdf

Graitson, D. (2006). La R\&D en Wallonie: état des lieux et perspectives. Liège: CESRW.

Gysen, M., Loosvelt, H., De Vuyst, J., Baert, F, Belmans, R. \& Lambrecht, M. (2006). Academisering ondersteunen en opvolgen. Leuven: Associatie K.U.Leuven.

High Level Group 3\% Belgium (2005). Research, technology and innovation in Belgium: The missing links. Brussels: Belgian Science Policy.

Ministère de la Communauté Française (2006). Statistiques de l'enseignement de plein exercice et budget des dépenses d'enseignement. Annuaire 2004-2005. Volume I. Bruxelles: ETNIC. 
Ministeriële Commissie Optimalisatie en Rationalisatie in het hoger onderwijs (2009) Optimalisatie en rationalisatie van het hoger onderwijslandschap en -aanbod. Deel II van het vervolgrapport van de Ministeriële Commissie aan de heer Frank Vandenbroucke, Vlaams minister van Werk, Onderwijs en Vorming. Brussel, 2009.

Région Wallonne, Communauté Française (2005). Les actions prioritaires pour l'avenir wallon. s.l.: Région Wallonne, Communauté française.

Smolders, C., Velghe, J. \& Verstraete, A. (2000). De taakbelasting van het onderwijzend personeel in de Vlaamse Hogescholen. Gent: Departement Handelswetenschappen en Bestuurskunde. Gent : Hogeschool Gent.

Spruyt, E., Tan, B. \& Van Dyck, D. (2005-2006). Onderzoek binnen de academiseringsopdracht in de associaties met als casus de Associatie Universiteit \& Hogescholen Antwerpen. Tijdschrift voor Onderwijsrecht en Onderwijsbeleid, (4-5), 415433.

Van Looy, B., Lecocq, C., Belderbos, R., Faems, D., Veugelers, R., Van Haverbeke, W., Duysters, G. \& De Man, A.P. (2006). Samenwerking universiteiten, hogescholen, onderzoeksinstellingen, intermediairen en bedrijven. Een studie van de internationale literatuur. Brussel: VRWB.

Van Ryssen, S., Van Pelt, S. \& Wuyts, A. (2007). TETRA/HOBU Effect- en outputmeting. Brussel: IWT.

Vandenbroucke, F. (2006). Voortbouwen en vooruitzien. Beleidsbrief Onderwijs en Vorming 2006-2007. Brussel: Ministerie van de Vlaamse Gemeenschap.

Verhoeven, J. C. (2005). Hogescholen en Academisering, Tijdschrift voor Onderwijsrecht en Onderwijsbeleid, (6), 495-505.

Verhoeven, J. C., Devos, G., Smolders, C., Cools, W. \& Velghe, J. (2002). Hogescholen enkele jaren na de fusie. Antwerpen/Apeldoorn: Garant.

Vlaams Ministerie van Onderwijs en Vorming (2006). Statistisch Jaarboek van het Vlaams Onderwijs, Schooljaar 2005-2006. Brussel: Vlaams Ministerie van Onderwijs en Vorming.

Vlaamse Raad voor Wetenschapsbeleid (VRWB) (2004). Wetenschap en innovatie in Vlaanderen 2004-2010. Voorstellen voor een strategisch beleid. Brussel: VRWB.

Werkgroep Academisering (2005). Advies van 29 juni 2005. Brussel: Ministeriële Werkgroep Academisering.

Zwerts, E. \& Hollebosch, B. (2000). Inventarisatie van het projectmatig wetenschappelijk onderzoek en de maatschappelijke dienstverlening. Brussel: Vlaamse Hogescholenraad. 